\title{
Współczesna Gospodarka
}

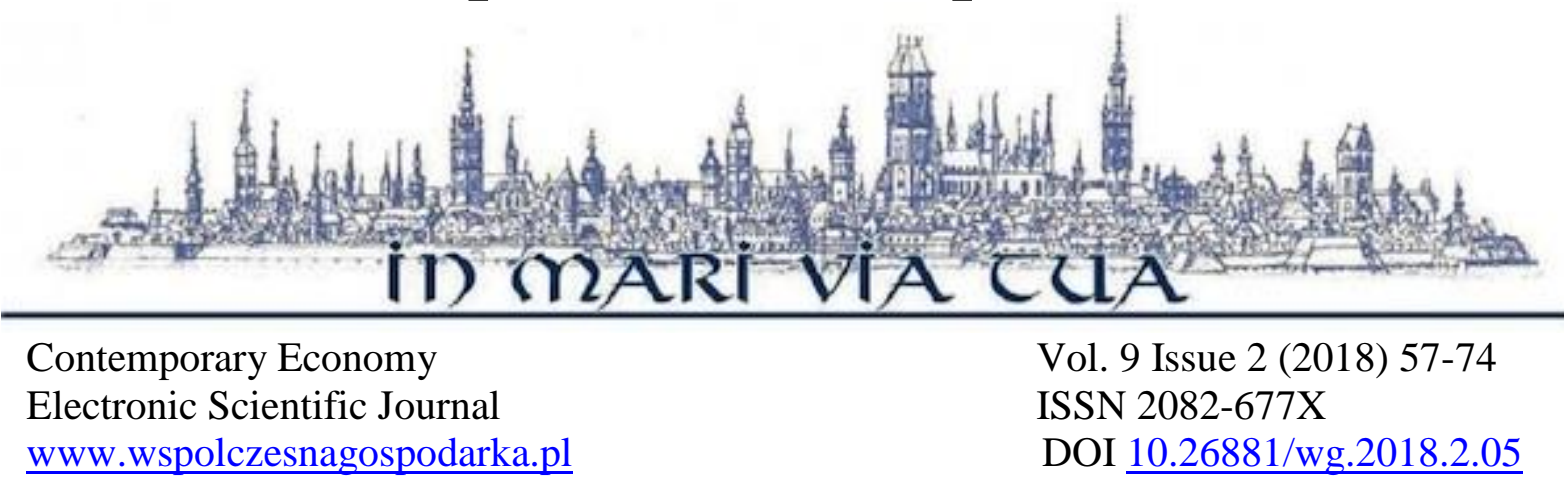

\author{
WPLYW INSTYTUCJI FORMALNYCH I NIEFORMALNYCH NA \\ ROZWÓJ PARTNERSTWA PUBLICZNO-PRYWATNEGO W POLSCE
}

\author{
Małgorzata Godlewska
}

\begin{abstract}
Streszczenie
Cel. PPP jest sprawdzoną i efektywną metodą realizacji inwestycji publicznych. Na rozwój PPP w Polsce wywierają wpływ zarówno instytucje formalne, jak i nieformalne. Celem artykułu jest określenie na podstawie badań empirycznych (jakościowych i ilościowych) oraz na podstawie krytycznego przeglądu literatury wpływu instytucji formalnych i nieformalnych na rozwój PPP w Polsce.

Metoda. Zastosowano podejście hybrydowe polegające na połączeniu kilku ilościowych i jakościowych metod badawczych tj. indywidualne wywiady pogłębione (IDI) $n=32$ z osobami odpowiedzialnymi za realizację projektów PPP po stronie sektora prywatnego $(\mathrm{n}=16)$ i publicznego $(\mathrm{n}=16)$; badanie ankietowe $\mathrm{n}=2.805$ jednostek samorządu terytorialnego w Polsce (ważne ankiety od $\mathrm{n}=257$ jednostek) oraz panel ekspertów z osobami posiadającymi wiedzę i doświadczenie w zakresie realizacji projektów PPP.

Wyniki. Partnerzy na rynku PPP darzą się ograniczonym zaufaniem. Rynek PPP w Polsce jest zdominowany przez mikroprojekty o wartości poniżej $5 \mathrm{mln}$ PLN, które są szansą na rozwój MSP. Kluczowy jest więc wpływ instytucji formalnych, jak i nieformalnych na MSP, aby zachęcić je do aktywnego uczestniczenia w postępowaniach na wybór partnera prywatnego. Efekt synergii można uzyskać dzięki współpracy instytucji formalnych z nieformalnymi, skierowanej na stworzenie środowiska sprzyjającego rozwojowi współpracy i wzajemnego zaufania pomiędzy partnerami.
\end{abstract}

Słowa kluczowe: partnerstwo publiczno-prywatne, instytucje formalne, instytucje nieformalne, ekonomiczna analiza prawa. 
Klasyfikacja JEL: D02, E02, K23, H70, B52

\section{Wstęp}

Partnerstwo publiczno-prywatne (zwane dalej PPP) jest sprawdzoną i efektywną metodą realizacji inwestycji publicznych (Renda i Schrefler 2006; Brzozowska 2010; Cenkier 2011; Herbst, Jadach-Sepioło 2012; Godlewska 2014, Kania 2014; Jachowicz 2015, Mazzucato 2016).

W ostatnich latach można zaobserwować globalny wzrost liczby projektów PPP na świecie, zwłaszcza mega projektów PPP o wartości powyżej 1 mld $\$$ (por. http://www.infrapppworld.com/pipeline-html/database-of-ppp-projects). W związku z nadmiernym długiem publicznym jaki powstał $\mathrm{w}$ wyniku stymulowania podczas globalnego kryzysu zapoczątkowanego w latach 2007/2008 większości gospodarek wysokorozwiniętych za pomocą pakietów fiskalnych na dużą skalę, państwa obecnie nie są w stanie samodzielnie finansować nowych kluczowych inwestycji infrastrukturalnych (Ferguson, 2014; Ptak, 2013). Nadmierne zadłużanie się państw przyczyniło się do wzrostu zainteresowania projektami PPP i wymusiło stworzenie nowych warunków dla potencjalnych partnerów prywatnych. PPP odgrywa znaczącą rolę w zapewnieniu bardziej przejrzystego, efektywniejszego, wiarygodniejszego, jak i lepiej zabezpieczonego procesu inwestycyjnego (Wojewnik-Filipkowska, Trojanowski, 2013).

Ponadto według raportu Market Update Review of the European PPP Market in 2016 liczba realizowanych projektów PPP o wartości transakcji powyżej $10 \mathrm{mln}$ EUR i z modelem współpracy pomiędzy partnerami DBFO (projektuj-buduj-finansuj-eksploatuj)/DBFM (projektuj-buduj-finansuj-utrzymuj) wzrosła w 2016 roku w porównaniu do 2015 roku o $41 \%$. Obecnie największy rynek PPP w Europie jest w Wielkiej Brytanii, Francji, Holandii, Niemczech, Słowacji, Irlandii czy Włoszech. Polska w 2016 roku podpisała tylko 2 umowy PPP o wartości transakcji powyżej $10 \mathrm{mln}$ EUR z modelem współpracy między partnerami DBFO/DBFM tj. koncesje na usługi polegające na organizacji imprez i zarządzaniu Międzynarodowym Centrum Kongresowym oraz Halą Widowiskowo-Sportową Spodek w Katowicach o wartości 200 mln PLN oraz PPP w trybie PZP na budowę i eksploatację oczyszczalni ścieków w Mławie o wartości 50 mln PLN (European Investment Bank, 2017). Według danych Ministerstwa Rozwoju w latach 2009-2016 podpisano w Polsce 122 umowy o PPP, o łącznej wartości 5,96 mld PLN. 66,96\% projektów PPP ma wartość poniżej 20 mln PLN, a tylko 13,39\% realizowanych projektów PPP w Polsce ma wartość powyżej $100 \mathrm{mln}$ PLN. Należy zwrócić uwagę na to, iż rozwój PPP w Polsce nie jest równomierny, gdyż tylko 6 województw realizuje/realizowało 89 projektów PPP, a pozostałe 10 województw tylko 33 projekty. Najaktywniejszymi województwami, jeśli chodzi o liczbę realizowanych projektów PPP są najbogatsze województwa z największą liczbą zarejestrowanych przedsiębiorców na 10000 mieszkańców, największym PKB na 1 mieszkańca czy największą wartością dodaną na 1 mieszkańca, czyli województwa Mazowieckie (23 projekty PPP); Śląskie (19 projektów PPP); Małopolskie (14 projektów PPP); Pomorskie (12 projektów PPP); Dolnośląskie (11 projektów PPP) oraz Wielkopolskie (10 projektów PPP) (Platforma Partnerstwa Publiczno-Prywatnego, dostęp: 31.05.2017). 
Co więcej, skala potrzeb inwestycyjnych w Polsce w zakresie dostarczania infrastruktury publicznej jest ogromna, co wynika ze stosunkowo skromnego majątku trwałego oraz jego dużego stopnia zużycia. Powoduje to konieczność odtworzenia majątku trwałego, co pociąga za sobą znaczne nakłady inwestycyjne brutto, które w sektorze dostarczania infrastruktury publicznej powinny wynieść w Polsce w latach 2011-2022 około 1150 mld PLN. Roczna luka finansowa (brakujące środki w sektorze publicznym) w latach 2011-2022 wahać się będzie pomiędzy 116 mld PLN a 197 mld PLN (w cenach stałych roku 2009) (Orłowski, 2011; Jachowicz, 2015). Według autorów raportu Building New Europe's Infrastructure. PPP in Central and Eastern Europe Polska ma największą lukę spośród państw Europy Środkowo-Wschodniej w zakresie brakującej infrastruktury (PriceWaterhouseCoopers, 2013).

W latach 2007-2013 Polska otrzymała w ramach Funduszy Strukturalnych Unii Europejskiej i Funduszu Spójności 67.9 mld euro (tj. ok 285 mld PLN) ze środków Unii Europejskiej (zwanej dalej UE) (Portal Funduszy Europejskich, dostęp: 31.07.2016). Te ogromne „darmowe" pieniądze z UE spowodowały duże zwolnienie tempa rozwoju PPP w Polsce. Fundusze UE są alternatywnym do PPP i znacznie szybszym sposobem na sfinansowanie nowych inwestycji infrastrukturalnych. Dodatkowo negatywny wpływ na rozwój PPP w Polsce miały obawy podmiotów publicznych o stabilność i adekwatność rozwiązań legislacyjnych związanych z PPP (PwC 2013, s. 3).

$\mathrm{Na}$ koniec 2013 r. łączne zadłużenie samorządowego sektora publicznego wynosiło 62.9 mld zł (Sawicki, 2014). Dług publiczny jednostek samorządu terytorialnego systematycznie rośnie na przestrzeni ostatnich latach (Korolewska, Marchewka-Bartkowiak, 2011), w przyszłości zatem jedynym możliwym rozwiązaniem sfinansowania inwestycji w nową infrastrukturę i dobra publiczne może być właśnie PPP (Wieloński 2014, Korbus, 2015). Ponadto zgodnie $\mathrm{z}$ art. 18a ust. 1 ustawy z dnia 19 grudnia 2008 r. o partnerstwie publiczno-prywatnym (zwaną dalej u.p.p.p.) zobowiązania wynikające $\mathrm{z}$ umów o PPP nie wpływają na poziom państwowego długu publicznego oraz deficyt sektora finansów publicznych, w sytuacji gdy partner prywatny ponosi większość ryzyka budowy oraz większość ryzyka dostępności lub ryzyka popytu.

W latach 2014-2020 Polska w ramach Funduszy Strukturalnych UE będzie miała do rozdysponowania 82.5 mld EUR, na podstawie Umowy Partnerstwa - Programowanie perspektywy finansowej 2014-2020 z dnia 23 maja 2014 r. (Portal Funduszy Europejskich, 2014). Tym niemniej, w latach 2014-2020, w związku z nowym indywidualnym wskaźnikiem zadłużenia jednostek samorządu terytorialnego (stanowiących największą grupę potencjalnych partnerów publicznych) część z nich nie będzie mogła zaciągać nowych zobowiązań finansowych i tym samym korzystać ze środków unijnych (Korbus, 2015), chyba że wkład własny za jednostkę samorządu terytorialnego wniesie partner prywatny, w związku z realizacją hybrydowego projektu PPP, na podstawie art. 63 Rozporządzenia Parlamentu Europejskiego i Rady (UE) nr 1303/2013 z dnia 17 grudnia 2013 r.

Na rozwój PPP w Polsce wpływ wywierają zarówno instytucje formalne, jak i nieformalne. Celem artykułu jest określenie na podstawie badań empirycznych (jakościowych i ilościowych) oraz na podstawie krytycznego przeglądu literatury wpływu instytucji formalnych i nieformalnych na rozwój PPP w Polsce. 


\section{Instytucje a PPP}

W niniejszym artykule termin partnerstwo publiczno-prywatne obejmuje zakres przedsięwzięć realizowanych zgodnie z ustawą z dnia 21 października 2016 r. o umowie koncesji na roboty budowlane lub usługi (zwaną dalej u.k.r.b.u.) oraz u.p.p.p.

Współpraca partnera prywatnego z partnerem publicznym jest oparta w Polsce o szczegółowe uregulowania wynikające z prawa unijnego tj. dyrektywy klasycznej 2014/24/UE, dyrektywy sektorowej 2014/25/UE jak i koncesyjnej 2014/23/UE oraz ustawy z dnia 29 stycznia 2004 r. Prawo zamówień publicznych (zwana dalej u.p.z.p.), u.k.r.b.u. i u.p.p.p. wraz z aktami wykonawczymi jak np. Rozporządzenie Ministra Gospodarki z dnia 11 lutego 2015 r. w sprawie rodzajów ryzyka oraz czynników uwzględnianych przy ich ocenie.

\subsection{Charakterystyka otoczenia instytucjonalnego PPP w Polsce}

PPP w Polsce zgodnie z art. 1 ust. 2 u.p.p.p. jest wspólną realizacją przedsięwzięcia,przez podmiot publiczny i partnera prywatnego opartego na podziale zadań i ryzyk między partnerami. Ponadto zgodnie z art. 2 ust. 4 u.p.p.p. przedsięwzięcie PPP może obejmować różnego rodzaju świadczenia np. budowę lub remont obiektu budowlanego, świadczenie usług, wykonanie dzieła czy inne świadczenia połączone każdorazowo z utrzymaniem lub zarządzaniem składnikiem majątkowym, który jest wykorzystywany do realizacji przedsięwzięcia PPP lub jest z nim związany. Warto podkreślić, iż u.p.p.p. nie określa modelu organizacyjno-prawnego współpracy pomiędzy partnerem publicznym i prywatnym, pozostawiając stronom względną swobodę w wyborze formy dostosowanej do specyfiki przedsięwzięcia PPP. Na uwagę zasługuje również wybór partnera prywatnego, który w Polsce jest możliwy w oparciu o trzy podstawy prawne wyboru partnera prywatnego, a mianowicie art. 4 ust. 1 u.p.p.p., art. 4 ust. 2 u.p.p.p. oraz art. 4 ust. 3 u.p.p.p. (Ministerstwo Gospodarki, 2014; Ministerstwo Rozwoju, 2017, s. 5-6). Przepis art. 4 ust. 1 u.p.p.p. stanowi, że wynagrodzeniem partnera prywatnego za wykonanie robót budowlanych jest wyłącznie prawo do eksploatacji obiektu budowlanego będącego przedmiotem umowy albo takie prawo wraz z płatnością (umowa koncesji na roboty budowlane) na podstawie art. 3 ust. 2 pkt 1 u.k.r.b.u., a za świadczenie usług i zarządzania tymi usługami wynagrodzeniem partnera prywatnego jest wyłącznie prawo do wykonywania usług będących przedmiotem umowy albo takie prawo wraz z płatnością (umowa koncesji na usługi) na podstawie art. 3 ust. 2 pkt 2 u.k.r.b.u. W takich przypadkach wyboru partnera prywatnego dokonuje się stosując odpowiednio przepisy u.k.r.b.u. W przeciwnym wypadku, przewidzianym $\mathrm{w}$ art. 4 ust. 2 u.p.p.p., tj., kiedy wynagrodzenie partnera prywatnego pochodzić będzie W całości albo w większości z zapłaty sumy pieniężnej z budżetu podmiotu publicznego (tzw. opłata za dostępność), do wyboru partnera prywatnego oraz do zawarcia umowy o PPP zastosowanie znajdą przepisy u.p.z.p. W rzadkich sytuacjach, ze względu na przepis szczególny, wyłączony jest obowiązek stosowania procedur ustawowych do wyboru partnera prywatnego/koncesjonariusz, gdy zgodnie z art. 4 u.k.r.b.u. szacunkowa wartość umowy koncesji jest niższa niż wyrażona $\mathrm{w}$ złotych równowartość 30000 EUR lub zgodnie $\mathrm{z}$ art. 4 ust. 8 u.p.z.p., gdy wartość zamówień publicznych i konkursów nie przekracza wyrażonej w złotych równowartości kwoty 30000 EUR. Wtedy wybór partnera prywatnego będzie musiał nastąpić stosownie do postanowień art. 4 ust. 3 u.p.p.p., tj. w sposób gwarantujący zachowanie uczciwej i wolnej konkurencji oraz przestrzeganie zasad równego traktowania, przejrzystości 
i proporcjonalności, przy odpowiednim uwzględnieniu przepisów u.p.p.p. (Ministerstwo Rozwoju, 2017, s. 5-6).

Natomiast według Rozporządzenia Parlamentu Europejskiego i Rady (UE) nr 1303/2013 z dnia 17 grudnia 2013 r. PPP oznacza formę współpracy między partnerem publicznym i prywatnym, której celem jest poprawa realizacji inwestycji w projekty infrastrukturalne lub inne rodzaje operacji realizujących usługi publiczne, poprzez dzielenie ryzyka, wspólne korzystanie ze specjalistycznej wiedzy sektora prywatnego lub dodatkowe źródła kapitału. Tak więc położony został nacisk Parlamentu Europejskiego na realizację zasady best value for money przy projektach PPP.

Co więcej, PPP może doprowadzić do zniwelowania luki w niedoborze infrastruktury, jak i zapewnić niezbędne finansowanie inwestycji przez partnera prywatnego, ale do tego potrzebne są silne instytucje formalne, elastyczne regulacje oraz przychylność polityczna. Polska podjęła działania $\mathrm{w}$ kierunku poprawienia procesu zawierania i realizacji projektów PPP, ale wciąż wiele $\mathrm{z}$ tych planowanych działań pozostaje tylko na papierze. Polskie otoczenie instytucjonalne, które jest niezbędne dla prawidłowego rozwoju projektów PPP zostało ocenione na 52.0 według indeksu Infrascope, co dało Polsce szóste miejsce wśród krajów Europy Środkowo-Wschodniej za Chorwacją (63.5), Litwą (62.9), Słowenią (61.8), Łotwą (54.4) i Węgrami (53.8). Polska dostała niskie oceny za ramy instytucjonalne oraz regulacyjne. Słabością Polski jest brak jasnych wytycznych, w oparciu o istniejące regulacje, dotyczących wybrania właściwej formy współpracy organizacyjno-prawnej, pomiędzy stroną publiczną a prywatną. Dodatkowo partnerzy publiczni borykają się z problemem zastosowania właściwej podstawy prawnej do wyboru partnera prywatnego. Ponadto, w przeszłości partner publiczny był zobowiązany do przeprowadzenia analizy przedrealizacyjnej planowanej inwestycji, na podstawie nieobowiązującego już rozporządzenia Ministra Finansów z dnia 30 czerwca 2006 r. w sprawie niezbędnych elementów analizy przedsięwzięcia w ramach partnerstwa publicznoprywatnego. Dzięki przeprowadzeniu takiej analizy partner publiczny był w stanie określić, czy PPP jest faktycznie najkorzystniejszym sposobem realizacji inwestycji publicznej oraz wyliczyć okres zwrotu z inwestycji. Przeprowadzenie takiej analizy ułatwiało partnerowi publicznemu podjęcie decyzji w sprawie podstawy wyboru partnera prywatnego, jak i formy współpracy organizacyjno-prawnej. Obecnie tylko nieliczni partnerzy publiczni przeprowadzają takie analizy przedrealizacyjne. Inne słabości polskiego otoczenia instytucjonalnego to brak koordynacji realizowanych projektów PPP na poziomie krajowym, regionalnym i lokalnym, np. pod kątem zgodności z Narodową Strategią Spójności czy regionalnymi strategiami rozwoju. Dużym problemem jest też niska skuteczność oraz niska efektywność ogłaszanych postępowań na wybór partnera prywatnego, w odniesieniu do liczby zawartych umów na realizacje projektów PPP, jak i do liczby projektów PPP, które uzyskały fazę zamknięcia finansowego (The Economist Intelligence Unit, 2012).

Warto także zwrócić uwagę na fakt, iż mimo podjęcia pierwszej próby uregulowania PPP w Polsce już w 2005 roku ustawą z dnia 28 lipca 2005 r. o partnerstwie publiczno-prywatnym, która weszła w życie w dniu 7 października 2005 r., to dopiero w dniu 26 lipca 2016 roku Rada Ministrów przyjęła politykę rozwoju PPP w Polsce. Do 2015 roku za rozwój PPP w Polsce odpowiedzialne było zarówno Ministerstwo Gospodarki, jak i Ministerstwo Infrastruktury i Rozwoju oraz Polska Agencja Rozwoju Przedsiębiorczości. Od końca 2015 r. za rozwój PPP w Polsce odpowiada Ministerstwo Rozwoju. Uchwalona „Polityka Rządu w zakresie rozwoju 
Partnerstwa Publiczno-Prywatnego" traktuje PPP, jako alternatywną i równoważną z tradycyjnymi metodami formułę realizacji inwestycji publicznych. Ponadto Rząd Rzeczypospolitej Polskiej (w szczególności Ministerstwo Rozwoju), w celu zapewnienia efektywnego wykorzystania formuły PPP w Polsce, planuje m.in. opracowanie i szerokie upowszechnienie wytycznych, wzorów umów, dobrych praktyk do wykorzystania przez podmioty publiczne zainteresowane stosowaniem PPP; wprowadzenie niezbędnych zmian prawnych w celu wdrożenia usprawnień dla PPP w Polsce; udzielanie kompleksowego bezpłatnego doradztwa wybranym projektom PPP czy opracowanie i wdrożenie obligatoryjnej oceny zasadności realizacji projektów planowanych do finansowania $\mathrm{w}$ kwocie powyżej 300 mln PLN z budżetu państwa w formule innej niż PPP (tzw. „negatywny test PPP”). Podjęcie ww. działań zdaniem Ministerstwa Rozwoju doprowadzi w latach 2017-2020 do: i) wzrostu liczby realizowanych inwestycji PPP; ii) zawarcia co najmniej 100 nowych umów PPP; iii) wzrostu udziału wartości podpisanych umów PPP w nakładach inwestycyjnych $\mathrm{w}$ gospodarce narodowej $\mathrm{w}$ sektorze publicznym do poziomu 5\%; iv) wzrostu liczby postępowań wszczętych przez sektor rządowy celem wyboru partnera prywatnego (wszczęcie co najmniej 10 takich postępowań); v) wzrostu liczby podpisanych umów PPP, w relacji do liczby ogłoszeń o wyborze partnera prywatnego do $40 \%$.

\subsection{Instytucje formalne $i$ nieformalne}

Na rozwój PPP w Polsce wywierają wpływ zarówno instytucje formalne jak i nieformalne, dlatego kluczowym jest ich zdefiniowanie.

W literaturze przedmiotu niektórzy badacze definiuje instytucje bardzo wąsko, tylko jako normy prawne. Tym niemniej, zdaniem autorki, definiując instytucje należy zwracać uwagę na ich formalny i nieformalny charakter, gdyż kompleksowe ramy instytucjonalne obejmują nieformalne ograniczenia, których źródłem jest kultura, formalne zasady oraz ich egzekwowanie (North, 1990). Instytucje według większości badaczy obejmują więc zarówno instytucje nieformalne, takie jak: zwyczaje społeczne, konwencje społeczne, normy społeczne, wspólne zrozumienie, standardy społeczne czy spontaniczne rozkazy, jak i instytucje formalne, takie jak normy prawne (Nozick, 1974; Argandona, 1991).

Według rankingu Global Competitiveness Index Światowego Forum Ekonomicznego polskie instytucje zostały sklasyfikowane na 65 miejscu (na 138 ocenianych państw), co świadczy o słabości polskich instytucji formalnych. Najsłabiej, w ramach filaru instytucji, zostało ocenione obciążenie rządowymi regulacjami (119); przejrzystość stanowienia prawa w Polsce (109 miejsce), publiczne zaufanie do polityków (104 miejsce) oraz skuteczność ram prawnych (102 miejsce) (Schwab, 2016). Natomiast według rankingu Worldwide Governance Indicators Banku Światowego normy prawne, jak i jakość regulacji obowiązujących w Polsce zostały ocenione na 75-90\% (na 100\%), ale skuteczność polskiego rządu, jak i kontrola korupcji, już tylko na 50-75\% (Bank Światowy, 2016). Na uwagę zasługują też wyniki rankingu Doing Business, który sklasyfikował Polskę na 24 miejscu na 190 ocenianych państwa, pod względem łatwości w prowadzeniu biznesu. Tym niemniej, pod względem regulacji dotyczących założenia działalności gospodarczej Polska została skalsyfikowana na 107 miejscu (na 190), a pod względem egzekwowania umów na 55 miejscu, co dowodzi słabości polskich instytucji formalnych. Ponadto, według Diagnozy Społecznej z 2015 roku zaufanie do kluczowych państwowych instytucji formalnych w Polsce wynosiło 40\% do rządu i 41\% do sejmu (Czapliński, Panek, 
2015, s. 88). W państwach Europy Środkowo-Wschodniej należących w przeszłości do byłego bloku wschodniego można zaobserwować znacznie wyższe zaufanie do najbliższych i przyjaciół (instytucji nieformalnych) niż instytucji formalnych (Wasilczuk, 2015, s. 336). Co więcej według European Social Survey z 2014 roku odsetek osób powyżej 16 roku życia, które ufają innym ludziom wynosił w Polsce $13 \%$, co było jednym z najniższych wyników w UE. Ponadto Polacy najrzadziej spośród obywateli UE-28 wierzą $\mathrm{w}$ dobre intencje innych ludzi, gdyż zaledwie 24\% Polaków wobec 76\% Duńczyków w wieku 16 lat i więcej jest przekonanych, że większość ludzi stara się postępować uczciwie wobec innych (European Social Survey, 2014).

Z przeprowadzonego przez autorkę w ramach badań młodych naukowców SGH w Warszawie w 2015 roku panelu ekspertów oraz badań IDI z 16 partnerami publicznymi i 16 partnerami prywatnymi, którzy realizują projekty PPP w Polsce wynika, że na co dzień partnerzy we wzajemnych relacjach borykają się z brakiem zaufania, co rzutuje na jakość wzajemnej współpracy. Ponadto bez zaufania partnerów do siebie nie ma mowy o jakiejkolwiek współpracy i efektywnym realizowaniu projektów PPP. Partnerzy darzą się mocno ograniczonym zaufaniem, gdyż partnerzy publiczni nie ufają partnerom prywatnym, bo obawiają się, że Ci ostatni mogą postępować nieuczciwie wobec nich z chęci zysku. Partnerzy prywatni nie ufają partnerom publicznym, bo obawiają się, że deklaracje partnerów publicznych mogą być elementem gry wyborczej. Tak niski poziom zaufania do innych ludzi z jakim mamy do czynienia w Polsce, co potwierdzają przytoczone wyniki badań European Social Survey 2014 czy Diagnozy Społecznej 2015 może być czynnikiem ograniczającym rozwój PPP w Polsce.

Instytucje formalne wpływają na jakość i elastyczność regulacji dotyczących PPP. Natomiast instytucje nieformalne stymulują oddolną energię partnerów prywatnych, np. przedsiębiorczość, kreatywność czy innowacyjność poprzez kulturowy system norm sprzyjających podejmowaniu ryzyka, współpracy czy samorealizacji (Phelps, 2013).

\subsection{Wpływ instytucji na rozwój PPP w Polsce}

Z przeprowadzonych przez autorkę w ramach badań młodych naukowców SGH w Warszawie w okresie czerwiec-wrzesien 2015 r. badań ankietowych z jednostkami samorządu terytorialnego (stanowiącymi największą grupę wśród partnerów publicznych tj. 91.96\%) wynika, iż instytucje formalne tj. normy prawne nie stymulują rozwoju PPP w Polsce (zobacz rysunek 1). 


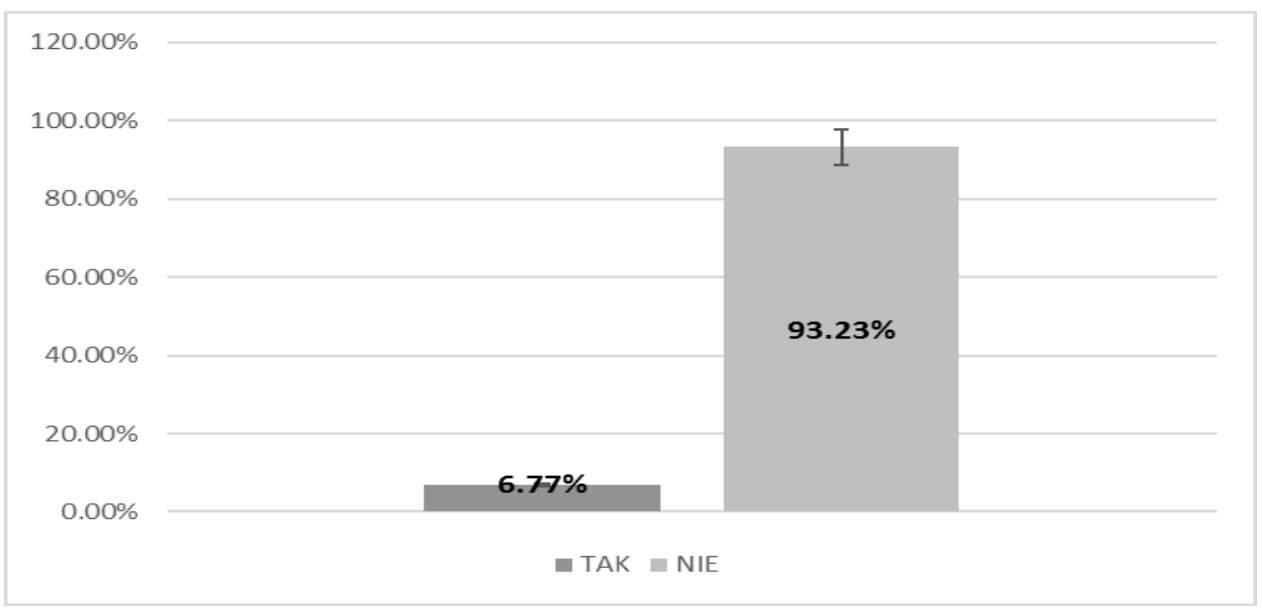

Rysunek 1. Czy instytucje formalne (normy prawne) stymulują rozwój PPP w Polsce?

Źródło: Opracowanie własne na podstawie przeprowadzonego badania ankietowego $\mathrm{n}=257$ jednostek samorządu terytorialnego.

W 69 umowach o realizację projektów PPP ze 112 zawartych w okresie od 2009 r. do 31.12.2016 r. konieczne było zorganizowanie finansowania nakładów inwestycyjnych poprzez doprowadzenie do zamknięcia finansowego. W 85.51\% umów o realizację projektów PPP zadanie pozyskania środków finansowych na realizację projektu PPP w całości spoczywało na partnerze prywatnym i to on ponosił ryzyko z tym związane. Tylko w $14.49 \%$ umów o realizację projektów PPP za pozyskanie finansowania infrastruktury częściowo odpowiadał partner publiczny, a częściowo partner prywatny (Ministerstwo Rozwoju, 2017). Tym niemniej zdaniem $76 \%$ jednostek samorządu terytorialnego (partnerów publicznych) wariant mieszany zakładający częściowe finansowanie infrastruktury przez partnera publicznego, jak i prywatnego w zależności od dokonanego podziału zadań i ryzyk najlepiej wspiera rozwój PPP. Tylko 7\% jednostek samorządu terytorialnego było zdania, że zapewnienie finansowania infrastruktury w 100\% przez partnera prywatnego wspiera rozwój PPP (zobacz rysunek 2). Tak więc w praktyce partnerzy publiczni, w tym jednostki samorządu terytorialnego starają się scedować zadanie zapewnienia finansowania infrastruktury na partnera prywatnego, mimo iż koszt pozyskania finansowania zewnętrznego jest w takim przypadku dużo wyższy (Sawicki, 2014). 
wariant mieszany zakładający częściowe finansowanie przez partnera publicznego i prywatnego w zależności od dokonanego podziału zadań i ryzyka.

100\% finansowania ze środków prywatnych

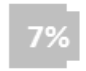

$100 \%$ finansowania ze środków publicznych, w tym dofinansowanie z Unii Europejskiej

Rysunek 2. Jaka struktura finansowania przedsięwzięcia PPP wspiera jego rozwój?

Źródło: Opracowanie własne na podstawie przeprowadzonego badania ankietowego $n=257$ jednostek samorządu terytorialnego.

U.p.p.p. nie determinuje modelu podziału ryzyk między partnerem publicznym a prywatnym. Tym niemniej, aby można było mówić o koncesji zgodnie z u.k.r.b.u to koncesjonariusz musi ponosić w zasadniczej części ryzyko ekonomiczne wykonania koncesji, szczególnie ryzyka popytu i dostępności (Ministerstwo Rozwoju, 2017). Zgodnie z rozporządzeniem Ministra Gospodarki z dnia 11 lutego 2015 r. w sprawie rodzajów ryzyka oraz czynników uwzględnianych przy jego ocenie, z realizacją projektów PPP związane są trzy główne rodzaje ryzyka, a mianowicie ryzyko budowy (obejmujące zdarzenia powodujące zmianę kosztów lub terminów wytworzenia nowych środków trwałych lub ulepszenia istniejących), dostępności (obejmuje zdarzenia skutkujące niższą ilością lub gorszą jakością świadczonych w ramach PPP usług w porównaniu z uzgodnieniami z umowy) oraz popytu (obejmuje zmienność popytu na określone usługi). Jednostki samorządu terytorialnego najbardziej preferują przeniesienie ryzyka popytu, budowy i dostępności na partnera prywatnego. mimo iż w większości przypadków może się to wiązać z wyższymi kosztami transakcyjnymi, jeśli partner prywatny skalkuluje to ryzyko i odpowiednio podniesie swoje honorarium, aby się zabezpieczyć na wypadek zmaterializowania się wszystkich ryzyk (zobacz rysunek 3). Ponadto ryzyko, zgodnie z założeniami PPP, powinien ponosić partner, który potrafi nim najlepiej zarządzać, a w przypadku ryzyk, na które żaden z partnerów nie ma wpływu, to takie ryzyko powinien ponosić partner publiczny (Collins, Pitt, Walls, 2006).

U.p.p.p. nie narzuca partnerowi publicznemu żadnego konkretnego modelu organizacyjno-prawnego współpracy $\mathrm{z}$ partnerem prywatnym przy realizacji projektów PPP. Partner publiczny może swobodnie dokonać wyboru formy odpowiedniej do specyfiki przedsięwzięcia PPP, która powinna być pochodną wstępnie przyjętego rozkładu ryzyka, a także sposobu finansowania planowanego przedsięwzięcia PPP (Ministerstwo Gospodarki, 2014, s. 17-18). Na świecie najczęściej spotykane modele współpracy (typy umów PPP) partnera publicznego z prywatnym to DBFO/DBFM (projektuj-buduj-finansuj-eksploatuj/projektuj-buduj-finansujutrzymuj), BTO (buduj-przekaż-eksploatuj), BOT (buduj-eksploatuj-przekaż) oraz BOO (bu- 
duj-posiadaj-eksploatuj) (Yescombe, 2008, s. 32). Według jednostek samorządu terytorialnego najbardziej preferowany model współpracy to BOT (buduj-eksploatuj-przekaż) oraz DBOT (projektuj-buduj-eksploatuj-przekaż) (zobacz rysunek 4).

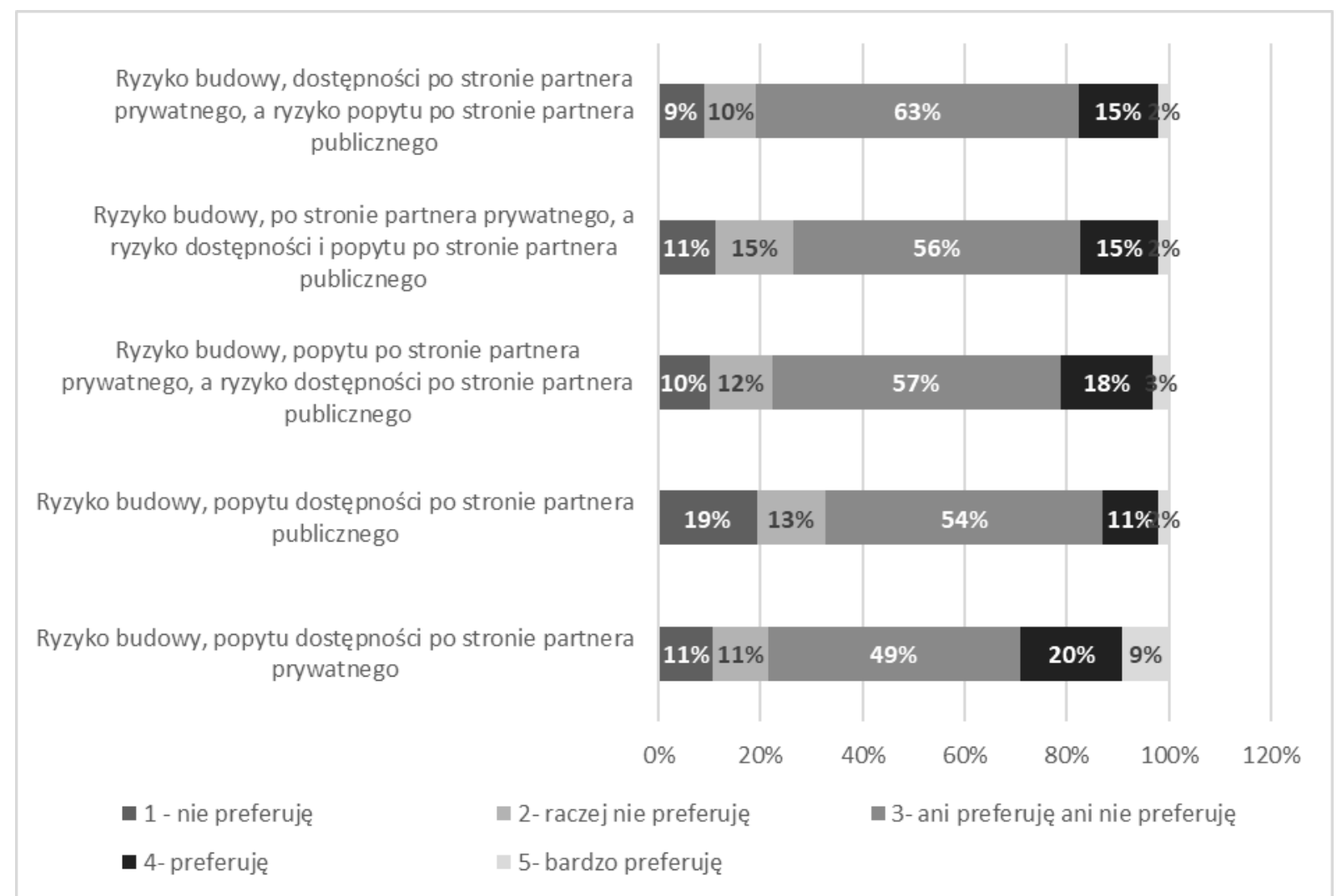

Rysunek 3. Najbardziej preferowany podział ryzyka pomiędzy partnerem publicznym i prywatnym.

Źródło: Opracowanie własne na podstawie przeprowadzonego badania ankietowego $\mathrm{n}=257$ jednostek samorządu terytorialnego. 


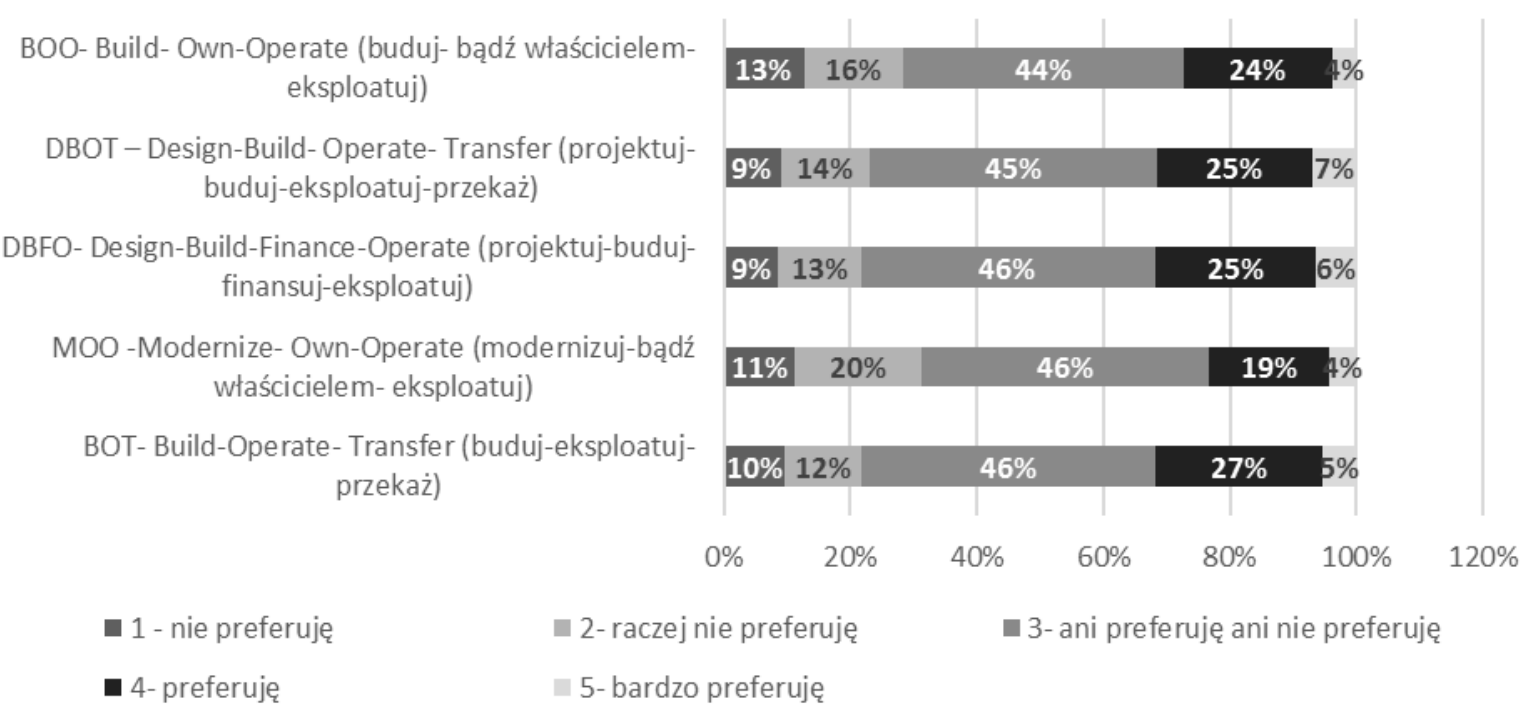

Rysunek 4. Najbardziej preferowany model współpracy partnera publicznego i prywatnego.

Źródło: Opracowanie własne na podstawie przeprowadzonego badania ankietowego $n=257$ jednostek samorządu terytorialnego.

Większość jednostek samorządu terytorialnego (93\%) nie ma wiedzy na temat kosztów transakcyjnych związanych z PPP (zobacz rysunek 5). Tylko 7\% jednostek samorządu terytorialnego wie jakie koszty transakcyjne są związane z realizowanymi projektami PPP. Mimo że instytucje formalne odgrywają kluczową rolę w procesie redukowania poziomu kosztów transakcyjnych (Coase, 1937; Williamson, 1985).

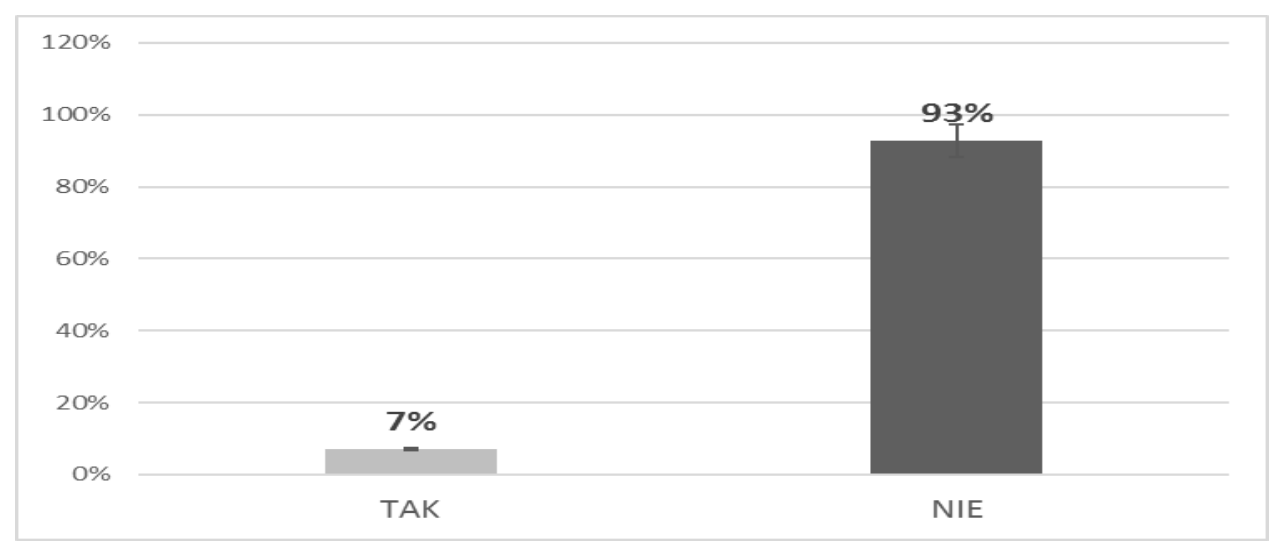

Rysunek 5. Czy wiedzą Państwo jakie koszty transakcyjne są związane z PPP w Polsce?

Źródło: Opracowanie własne na podstawie przeprowadzonego badania ankietowego $\mathrm{n}=257$ jednostek samorządu terytorialnego. 
Jednostki samorządu terytorialnego, które miały wiedzę na temat kosztów transakcyjnych związanych z PPP, wskazały na koszty doradztwa prawnego, finansowego i technicznego (41.67\%), koszty organizacji i prowadzenia postępowania na wybór partnera prywatnego/koncesjonariusz (22.22\%) czy koszty negocjacji zakresu zadań i podziału ryzyka pomiędzy partnerami (13.89\%) (zobacz rysunek 6).

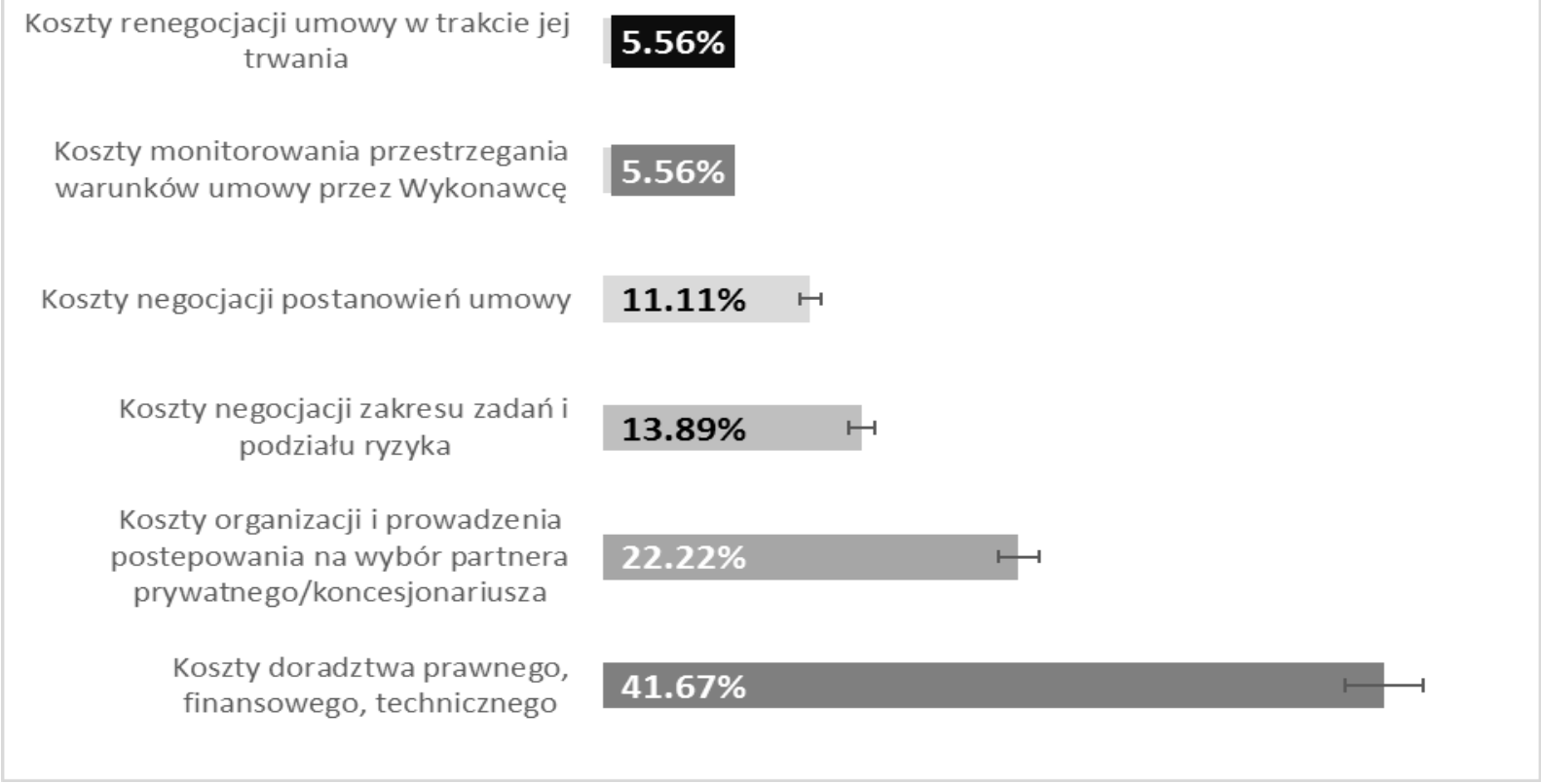

Rysunek 6. Koszty transakcyjne związane z realizowanymi projektami PPP.

Źródło: Opracowanie własne na podstawie przeprowadzonego badania ankietowego $\mathrm{n}=257$ jednostek samorządu terytorialnego.

Ponadto $32.26 \%$ jednostek samorządu terytorialnego uważa, że poziom kosztów transakcyjnych zależy od trybu wyboru partnera prywatnego, a $22.58 \%$ że od podziału zadań i ryzyk między partnerami. Zdaniem $12.90 \%$ jednostek samorządu terytorialnego, poziom kosztów transakcyjnych zależy od modelu współpracy czy struktury finansowania infrastruktury (zobacz rysunek 7). Poniższe wyniki potwierdzają wnioski Soliño i de Santos (2010). 


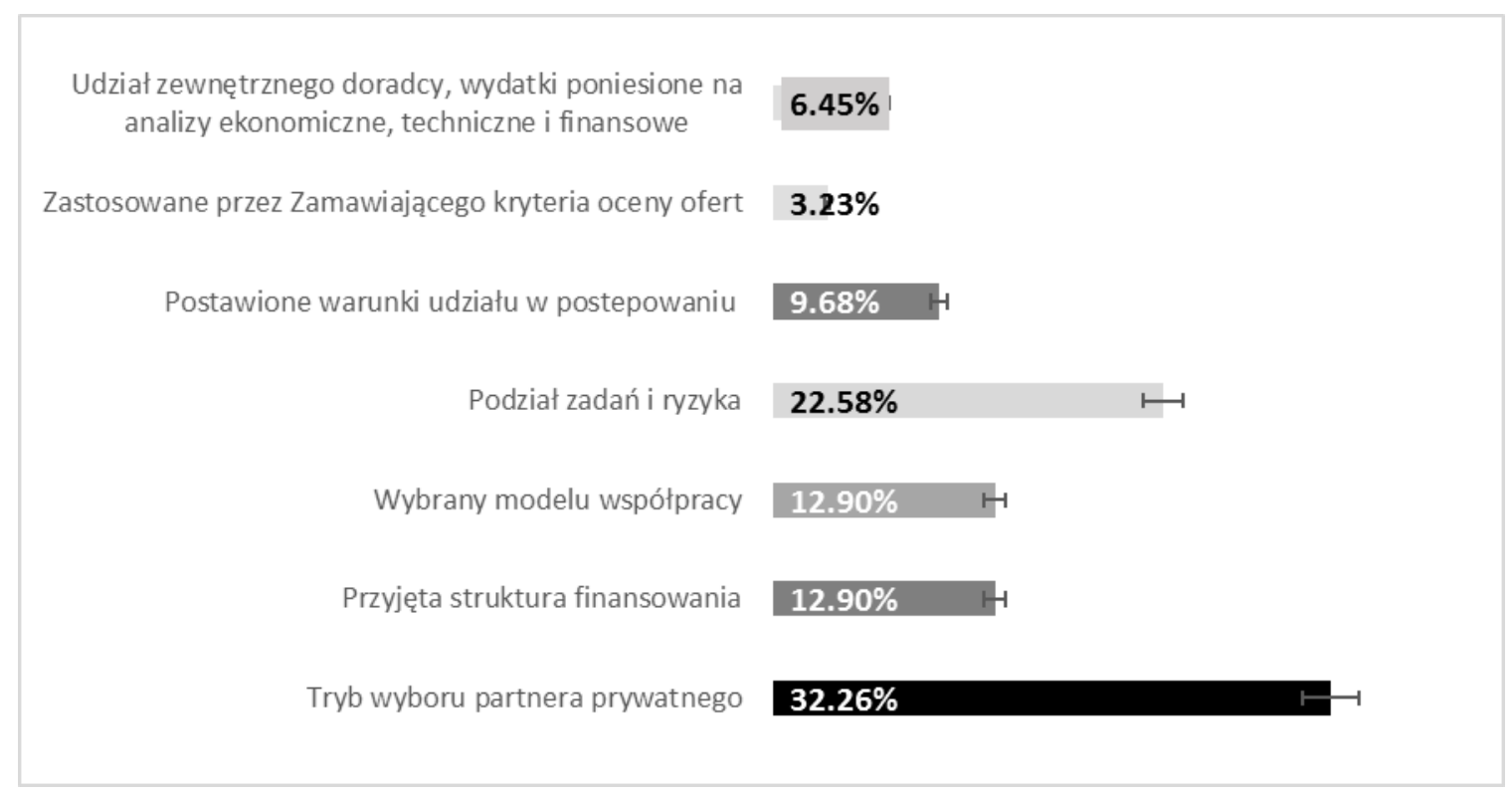

Rysunek 7. Od czego zależy poziom kosztów transakcyjnych związanych z realizowanym projektem PPP?

Źródło: Opracowanie własne na podstawie przeprowadzonego badania ankietowego $\mathrm{n}=257$ jednostek samorządu terytorialnego.

Koszty transakcyjne w projektach PPP mogą osiągać wartość od 1\% do 14\% wartości projektu PPP. Występują także różnice między poziomem kosztów transakcyjnych, ponoszonych przez partnerów publicznych (wyższe koszty) i partnerów prywatnych (niższe koszty) (Dudkin, Välila, 2005). Według innych szacunków koszty transakcyjne związane z projektami PPP mogą osiągać wartość od 3\% do 25\% wartości projektu PPP (Torres, Pina, 2001).

Natomiast z przeprowadzonego panelu ekspertów oraz badań IDI z 16 partnerami publicznymi i 16 partnerami prywatnymi, którzy realizują projekty PPP w Polsce wynika, iż przedsiębiorstwa duże (partnerzy prywatni) nie są zainteresowane projektami PPP o wartości poniżej 10 mln EUR, ze względu na koszty transakcyjne, jak i możliwość wniesienia małej wartości dodanej. Ponadto w Polsce koszty transakcyjne mogłyby być znacznie niższe, gdyby partnerzy publiczni mieli do dyspozycji wzorcowe dokumentacje na wybór partnera prywatnego/koncesjonariusza, a także wzorcowe umowy dla różnych rodzajów projektów PPP.

\section{Zakończenie}

W Polsce rynek PPP jest zdominowany przez mikroprojekty PPP o wartości poniżej $5 \mathrm{mln}$ PLN, które stanowią 43.75\% wszystkich realizowanych projektów PPP. Ponadto na 470 wszczętych przez podmioty publiczne postępowań na wybór partnera prywatnego w latach 2009-2016 zawarto tylko 122 umowy (Ministerstwo Rozwoju, 2017). Oznacza to, że podmiot publiczny musiał wszcząć 3,85 postepowań na wybór partnera prywatnego, aby finalnie być w stanie zawrzeć jedną umowę PPP z partnerem prywatnym. Ze względu na specyfikę polskiego rynku PPP oraz związane z projektami PPP koszty transakcyjne, przedsiębiorstwa duże nie 
są zainteresowane mikroprojektami PPP. Mikro i małe projekty PPP są szansą na rozwój małych i średnich przedsiębiorstw. Tym samym kluczowy jest wpływ instytucji formalnych oraz nieformalnych na małe i średnie przedsiębiorstwa, aby zachęcić je do aktywnego uczestniczenia w postępowaniach na wybór partnera prywatnego. Efekt synergii może dać współpraca instytucji formalnych z instytucjami nieformalnymi, skierowana na stworzenie środowiska sprzyjającego rozwojowi współpracy i wzajemnego zaufania pomiędzy partnerami. Tak więc kluczowe dla dalszego rozwoju PPP w Polsce są instytucje nieformalne, które poprzez zmianę wartości kulturowych mogą wpłynąc na wzrost zaufania, bo bez niego nie ma współpracy pomiędzy partnerami, a bez partnerstwa nie ma partnerstwa publiczno-prywatnego (Grendowicz, 2014).

Przydatnym instrumentem dla partnerów publicznych, chcących zwiększyć zaangażowanie małych i średnich przedsiębiorstw w realizację mikro i małych projektów PPP w Polsce może być praktyczne zaimplementowanie zasad „Europejskiego kodeksu najlepszych praktyk ułatwiających dostęp MSP do zamówień publicznych" do postępowań na wybór partnera prywatnego.

Instytucje formalne powinny też opracować na szczeblu krajowym, regionalnym i lokalnym listę planowanych do realizacji w przeciągu najbliższego roku projektów PPP (ang. project pipeline), aby potencjalni partnerzy prywatni mieli czas na przygotowanie się do udziału w tych postępowaniach, co jest szczególnie istotne w przypadku małych i średnich przedsiębiorstw. Warto też zwrócić uwagę na możliwość tworzenia klastrów projektów PPP przez instytucje formalne, tj. łączenia wielu mikro i małych projektów PPP o tym samym przedmiocie np. budowa mieszkań komunalnych czy efektywność energetyczna związana z wymianą oświetlenia ulic na bardziej energooszczędne, w jednym dużym postępowaniu na wybór partnera prywatnego.

\section{Bibliografia}

Argandona A. (1991). Values, Institutions, and Ethics. University of Navarra, Working Papers, 215, http://www.iese.edu/research/pdfs/DI-0215-E.pdf (dostęp: 29.11.2016).

Bank Światowy (2016). Worldwide Governance Indicators 2015, http://info.worldbank.org/governance/wgi/\#home (dostęp: 15.05.2017).

Brzozowska K. (2010). Partnerstwo publiczno-prywatne w Europie. Cele, uwarunkowania, efekty. Warszawa: Wydawnictwo Fachowe CeDeWu Sp. z o.o.

Cenkier A. (2011). Partnerstwo publiczno-prywatne jako metoda wykonania zadań publicznych. Warszawa: Oficyna Wydawnicza SGH.

Coase R.H. (1937). The Nature of the Firm.W: O.E.Williamson, S.E. Masten (red.), The Economisc of Transaction Costs. Cheltenham, UK, Northampton, MA, USA: An Elgar Critical Writings Reader.

Collins N., Pitt M., Walls A. (2006). The Private Finance Iniciative and Value for Money. "Journal of Property Investment \& Finance", t. 24, nr 4.

Czapliński J., Panek T. (2015). Diagnoza Społeczna 2015. Warunki i Jakość Życia Polaków, Warszawa: Rada Monitoringu Społecznego.

Dudkin G., Välila T. (2005). Transaction costs in Public-Private Partnerships: First Look at the Evidence. "EIB Economic and Financial Report", No 03/2005. 
European Investment Bank (2017). Market Update Review of the European PPP Market in 2016, http://www.eib.org/epec/resources/publications/epec_market_update_2016_en (dostęp: 10.05.2017).

European Social Survey (2014), http://www.europeansocialsurvey.org/download.html?file=ESS7e01\&y=2014 (dostęp: 15.05.2017).

Ferguson N. (2014). The Great Degeneration. How Institutions Decay and Economies Die, New York, Penguin Press.

Godlewska M. (2014). Partnerstwo publiczno-prywatne kluczem do stabilnego wzrostu, przykład Malezji. „Kwartalnik Nauk o Przedsiębiorstwie”, nr 3/2014, s. 99-104.

Godlewska M. (2015). Koszty transakcyjne, a rozwój partnerstwa publiczno-prywatnego w Polsce. „Zeszyty Naukowe Studia i Prace Kolegium Zarządzania i Finansów SGH w Warszawie", nr 141, s. 49-62.

Grendowicz M. (2014). Wzajemne zaufanie podstawa PPP, http://www.zamowieniapubliczne.lex.pl/czytaj/-/artykul/wzajemne-zaufanie-podstawa-ppp (dostęp: 05.06.2017).

Herbst I., Jadach-Sepioło A. (2012). Raport ze studiów przypadku PPP. Warszawa: Polska Agencja Rozwoju Przedsiębiorczości.

InfraPPP http://www.infrapppworld.com/pipeline-html/database-of-ppp-projects (dostęp: 06.06.2017).

Jachowicz A. (2015). Partnerstwo publiczno-prywatne narzędziem efektywnej realizacji zadań publicznych. Warszawa: Difin.

Kancelaria Prezesa Rady Ministrów (2017). ID62 Projekt uchwały Rady Ministrów w sprawie przyjęcia dokumentu "Polityka Rzadu w zakresie rozwoju Partnerstwa PublicznoPrywatnego", 2017, https://bip.kprm.gov.pl/kpr/form/r4229807151926,Projekt-uchwalyRady-Ministrow-w-sprawie-przyjecia-dokumentu-quotPolityka-Rzadu-.html (dostęp: 16.05.2017).

Kania M. (2014). Zamówienia publiczne, Partnerstwo publiczno-prywatne, Koncesja na roboty budowlane lub ustugi. Instytucje prawne realizacji przedsięwzięć Publicznych. Warszawa: Difin.

Korbus B. (2015). Rynek Partnerstwa publiczno-prywatnego i koncesji w kontekście potrzeb finansowych samorzadu terytorialnego w Polsce. [w:] B. Korbus (red.), Partnerstwo publiczno-prywatne. Realizacja zadań samorzadu lokalnego z partnerem prywatnym. Warszawa: Wydawnictwo C.H. Beck.

Korolewska M., Marchewka-Bartkowiak K. (2011). Zadtużenie samorzadów terytorialnych w Polsce. ,Studia Biura Analiz Sejmowych”, nr 4(28).

Mazzucato M. (2016). Przedsiębiorcze państwo. Obalić mit o relacji sektora publicznego $i$ prywatnego. Poznań: Wydawnictwo Ekonomiczne Heterodox.

Ministerstwo Gospodarki (2014). Partnerstwo publiczno-prywatne od pomystu do wyboru partnera prywatnego, Warszawa, http://ippp.pl/wp-content/uploads/2016/03/Partnerstwo-publiczno-prywatne-Instytut-PPP.pdf (dostęp: 15.05.2017).

Ministerstwo Rozwoju (2017). Analiza rynku PPP za okres od 2009 r. do 31 grudnia 2016 r., https://www.ppp.gov.pl/baza/Strony/baza_projektow_ppp.aspx (dostęp: 09.05.2017).

North D. C. (1990). Institutions, Institutional Change and Economic Performance. Cambridge: Cambridge University Press. 
Nozick R. (1974). Anarchy, State, and Utopia. New York, Basic Books, Inc.

Orłowski W.M. (2011), Potencjalne makroekonomiczne korzyści stosowania PPP w Polsce. Warszawa, Niezależny Ośrodek Badań Ekonomicznych NOBE.

Phelps E.S. (2013). Mass flourishing: how grassroots innovation created jobs, challenge, and change. Princeton: Princeton University Press.

Platforma Partnerstwa Publiczno-Prywatnego http://www.ppp.gov.pl/baza/Strony/baza_projektow_ppp.aspx/ (dostęp: 31.05.2017).

Portal Funduszy Europejskich (2016, 2014), https://www.funduszeeuropejskie.gov.pl (dostęp: 28.05.2017).

PriceWaterhouseCoopers (PwC) (2013). Building New Europe's Infrastructure. PPP in Central and Eastern Europe, http://pwc.blogs.com/files/building-new-europe39sinfrastructure---full-publication.pdf (dostęp: 10.05.2017).

Ptak P. (2013). Dlug publiczny w pogladach Jamesa Buchanana a kryzys zadtużenia na świecie. [w:] U. Zagóra-Jonszta, K. Nagel (red.), Współczesne problemy ekonomiczne, „Studia Ekonomiczne", Zeszyty Naukowe Wydziałowe nr 129, Katowice: Wydawnictwo Uniwersytetu Ekonomicznego w Katowicach.

Renda A., Schrefler L. (2006). Public-Private Partnerships. Models and Trends in the European Union, European Parlament, IP/A/IMCO/SC/2005-161.

Sawicki T. (2014). Partnerstwo publiczno-prywatne jako forma finansowania samorzadowych Inwestycji infrastrukturalnych. Szanse i zagrożenia. Dostępność finansowania dtugoterminowego dla projektów PPP, Studia BAS nr 3(39), s. 159-180.

Schwab K. (2016). The Global Competitiveness Report, edition 2016-2017, World Economic Forum, Geneva, https://www.weforum.org/reports/the-global-competitiveness-report2016-2017-1 (dostęp: 15.05.2017).

Soliño A.S., de Santos P.G. (2010). Transaction Costs in Transport Public-Private Partnerships: Comparing Procurement Procedures. "Transport Reviews”, vol. 30, no. 3, s. 389406.

The Economist Intelligence Unit (2012). Evaluating the environment for public private partnerships in Eastern Europe and the Commonwealth of Independent States The 2012 EECIS Infrascope. Pozyskano z: http://www.ebrd.com/downloads/news/eecis.pdf (10.05.2017).

Torres L., Pina V. (2001). Public- private partnership and private finance initiatives in the EU and Spanish local governments. "The European Accounting Review", vol. 10, no. 3, s. 601-619.

Wasilczuk J.E. (2015). Otoczenie instytucjonalne a innowacyjność przedsiębiorstw. „Zeszyty Naukowe Uniwersytetu Szczecińskiego". Nr 875, Problemy Zarządzania, Finansów i Marketingu, nr 41, t. 2.

Wieloński M. (2014). Partnerstwo publiczno-prywatne w Unii Europejskiej. Warszawa: Difin.

Williamson O.E. (1985). The Economic Institution of Capitalism. New York: The Free Press.

W. Wojewnik, Filipkowska A., Trojanowski D. (2013). Principles of public \& private partnership financing-Polish experience. "Journal of Property Investment \& Finance", vol. 31 issue: 4, s. 329-344. 
Yescombe E.R. (2008). Partnerstwo publiczno-prywatne. Zasady wdrażania i finansowania. Kraków: Wolters Kluwer Polska.

\section{Akty prawne:}

Traktat o funkcjonowaniu Unii Europejskiej wersja skonsolidowana (Dz.U. Unii Europejskiej C 202, 2016).

Dyrektywa Parlamentu Europejskiego i Rady 2014/23/UE z dnia 26 lutego 2014 r. w sprawie udzielenia koncesji (Dz. U. Unii Europejskiej L 94, 2014).

Dyrektywa Parlamentu Europejskiego i Rady 2014/24/UE z dnia 26 lutego 2014 r. w sprawie zamówień publicznych, uchylająca dyrektywę 2004/18/WE (Dz. U. Unii Europejskiej L 94, 2014).

Dyrektywa Parlamentu Europejskiego i Rady 2014/25/UE z dnia 26 lutego 2014 r. w sprawie udzielania zamówień przez podmioty działające w sektorach gospodarki wodnej, energetyki, transportu i usług pocztowych, uchylająca dyrektywę 2004/17/WE (Dz. U. Unii Europejskiej L 94, 2014).

Rozporządzenie Parlamentu Europejskiego i Rady (UE) nr 1303/2013 z dnia 17 grudnia 2013 r. ustanawiające wspólne przepisy dotyczące Europejskiego Funduszu Rozwoju Regionalnego, Europejskiego Funduszu Społecznego, Funduszu Spójności, Europejskiego Funduszu Rolnego na rzecz Rozwoju Obszarów Wiejskich oraz Europejskiego Funduszu Morskiego i Rybackiego oraz ustanawiające przepisy ogólne dotyczące Europejskiego Funduszu Rozwoju Regionalnego, Europejskiego Funduszu Społecznego, Funduszu Spójności i Europejskiego Funduszu Morskiego i Rybackiego oraz uchylające rozporządzenie Rady (WE) nr 1083/2006 (Dz. U. Unii Europejskiej L 347, 2013).

Ustawa z dnia 29 stycznia 2004 r. - Prawo Zamówień Publicznych ( Dz. U. z 2015 r. poz. 2164, z 2016 r. poz. 831, 996, 1020, 1250, 1265, 1579, 1920, 2260, z 2017 r. poz. 933).

Ustawa z dnia 19 grudnia 2008 r. o Partnerstwie Publiczno-Prywatnym (Dz. U. z 2015 r. poz. 696, 1777, 1920).

Ustawa z dnia 21 października 2016 r. o umowie koncesji na roboty budowlane lub usługi (Dz. U. z 2016 r., poz. 1920).

Ustawa z dnia 28 lipca 2005 r. o partnerstwie publiczno-prywatnym (Dz.U. 2005 nr 169 poz. 1420).

Rozporządzenie Ministra Gospodarki z dnia 11 lutego 2015 r. w sprawie rodzajów ryzyka oraz czynników uwzględnianych przy ich ocenie (Dz. U. z 2015 r. poz 284).

Rozporządzenia Ministra Finansów z dnia 30 czerwca 2006 r. w sprawie niezbędnych elementów analizy przedsięwzięcia $\mathrm{w}$ ramach partnerstwa publiczno-prywatnego (Dz. U. nr 125, poz. 866).

Europejski kodeks najlepszych praktyk ułatwiających dostęp MŚP do zamówień publicznych, Komisja Wspólnot Europejskich SEC (2008) 2193, 2008. 


\section{IMPACT OF FORMAL AND INFORMAL INSTITUTIONS ON DEVEL- OPMENT OF PUBLIC-PRIVATE PARTNERSHIP IN POLAND Abstract}

Purpuse: PPP is a proven and effective method of implementing public investment. PPP development in Poland is influenced by formal and informal institutions. The aim of the article is to determine, based on empirical research (qualitative and quantitative) and critical review of the literature, the influence of formal and informal institutions on PPP development in Poland.

Methodology: A hybrid approach was used to combine several quantitative and qualitative research methods: individual in-depth interviews (IDI) $\mathrm{n}=32$ with persons responsible for PPP projects by the side of private $(n=16)$ and public partners $(n=16)$; survey $n=2,805$ with local government units (valid questionnaires $n=257$ units) and panel with PPP experts.

Findings: PPP partners have limited trust to each other. PPP market in Poland is dominated by micro projects worth less than PLN 5 million, which are an opportunity for development of SMEs. So, the impact of formal and informal institutions directed to encourage SMEs to actively participate in the award procedure for private partner is crucial. The synergy effect may be achieved through the cooperation of formal and informal institutions focus on creating conducive environment for the development of cooperation and mutual trust between partners.

Keywords: public-private partnership, formal institutions, informal institutions, law \& economics.

JEL classification: D02, E02, K23, H70, B52

dr Małgorzata Godlewska

Szkoła Główna Handlowa w Warszawie, Kolegium Nauk o Przedsiębiorstwie, Katedra Prawa Administracyjnego i Finansowego Przedsiębiorstw

Adres pocztowy: al. Niepodległości 162, 02-554 Warszawa

Adres e-mailowy: mgodlews@sgh.waw.pl 